Gramáticas de la (¿post?) violencia:

identidades, guerras, cuerpos y fronteras

\title{
For Human Rights: Constructing the multinational Brčko District in Bosnia and Herzegovina
}

\author{
Andréa Carolina Schvartz Peres ${ }^{123}$ \\ - Universidade Federal de Roraima, Boa Vista/RR, Brasil \\ ${ }^{2}$ Centro Brasileiro de Análise e Planejamento, São Paulo/SP, Brasil \\ 3 Universidade Estadual de Campinas, Campinas/SP, Brasil
}

\begin{abstract}
The Brčko District was conceived to be a multiethnic political-administrative unit in post-war Bosnia and Herzegovina. Various efforts have been made to accomplish this since the year 2000, such as the construction of urban space with the equitable presence of the three national groups recognized by the Constitution of Bosnia and Herzegovina and the unification of the school system, both with the aim to guarantee human rights, understood as equal cultural rights. This article focuses on the educational system and the monuments policy to critically analyze these endeavors by revealing how policies for the construction of a multinational space have contributed to the maintenance of a divided city, where the borderlines do not need to be official to exist and constantly remind everyone to which group they belong to and what this means.
\end{abstract}

Keywords: Bosnia and Herzegovina; Education; Multiculturalism; Heritage; Brčko District; conflict. 


\section{Pelos direitos humanos: construindo o multinacional no Distrito de Brčko (Bósnia-Herzegóvina)}

\section{Resumo}

O Distrito de Brčko foi concebido como uma unidade político-administrativa multiétnica na BósniaHerzegóvina. Desde 200o, vários esforços foram feitos no sentido de consumá-la, como a construção de um espaço urbano com presença equitativa dos três grupos nacionais reconhecidos pela Constituição da Bósnia-Herzegóvina e a unificação do sistema escolar, com o objetivo de garantir direitos humanos, aqui traduzidos em direitos iguais e culturais. Esse artigo visa uma análise crítica desses esforços, com foco no sistema educacional e nas políticas de patrimônio, com o propósito de apontar como políticas de construção de um espaço multinacional contribuíram para a manutenção de uma cidade dividida, onde as linhas não precisam ser oficiais para existirem e lembrarem a todo o momento a qual grupo a pessoa pertence e o que isso significa.

Palavras-chave: Bósnia-Herzegóvina; Educação; Multiculturalismo; Distrito de Brčko; Patrimônio; Conflito. 


\title{
For Human Rights: \\ Constructing the multinational Brčko District in Bosnia and Herzegovina
}

\author{
Andréa Carolina Schvartz Peres
}

\section{Introduction}

The war raged on all fronts [...]. Mortar shells, psychological and real, wiped out people, houses, cities, children, bridges, memory. In the name of the present, a war was waged for the past; in the name of the future, a war against the present. In the name of a new future, the war devoured the future. Warriors, the masters of oblivion, the destroyers of the old state and builders of new ones, used every possible strategic method to impose a collective amnesia. The self-proclaimed masters of life and death set up the coordinates of right and wrong, black and white, true and false.

Dubravka Ugrešić, The Culture of Lies

Brčko is a small city in the district of the same name. Located in the northeastern Bosnia and Herzegovina region called Posavina, the city is flanked by the Sava River, which marks the border with Croatia. This country, like Bosnia and Herzegovina, was part of the former Yugoslavia before the wars of the 1990s. ${ }^{1}$ Stories are told until today of the dismemberment of this country, about its populations, and about the wars.

Bosnia and Herzegovina is often depicted by the media as a heterogeneous and plural mosaic of peoples, with the war commonly explained as a conflict between three distinct peoples (Cf. Peres 2005). Yet I remember being puzzled upon arriving in the country for the first time (in 2007) by the apparent similarity and lack of visible differences among groups described as distinct. The same language was heard, the same songs were played in radios, cafes and bars, the same video clips were broadcast by the TV channels I had access to in all parts of the former Yugoslavia - and I saw similar clothing, faces and habits. The emblematic place of difference was revealed in the prayers heard at religious temples; and especially in names and in the stories told.

It is even said that the war was waged based on names. Most were seen as nearly irrefutable proof of "national difference", which is how the differentiation between Serbs, Croats and Muslims (who in 1993 were renamed Bosniacs) was described in the former Yugoslavia and until today. It could be said that these groups had their origins in the different religious communities: Orthodox Christians, Catholics and Muslims, respectively. This fact reminds us that the political organization of states has not always had a national character, as in the Ottoman Empire, which ruled the region until the Balkan Wars of the early twentieth century, when religion was the basis for classification of the populations.

\footnotetext{
1 The use of "former" is intended to differentiate between the socialist Yugoslavia (1945-1991) and Yugoslavia (the Federal Republic of Yugoslavia) formed by Serbia and Montenegro (from 1992 to 2003).
} 
The twentieth century, however, was a century of few gods, especially in socialist and atheist regimes. This fact had consequences in the former Yugoslavia, both in terms of secularism, and resentment of religious people, who were denied positions in power.

Names, however, remained more than any other social marker of difference in the former Yugoslavia. Thus, at the beginning of the war in Brčko, a journalist from Radio Brčko was approached by a not-sofriendly soldier asking for his name. Stunned by the absurdity of the question, the journalist was reluctant to answer, until he realized the gravity of the question. "Savo", he finally replied. It was the correct name in that case. Meanwhile, Zijad, a train driver, was not so lucky when asked the same question, and was consequently beaten and imprisoned in his own city, which he affirmed had become a large concentration camp. ${ }^{2}$

Before Brčko was invaded and occupied by Serbian troops, the war had already flared in several parts of Bosnia and Herzegovina, many regions had already been proclaimed Serbian Autonomous Regions (SAOs), ${ }^{3}$ and the war in Croatia was only temporarily suspended. ${ }^{4}$ According to countless reports, the Serbian troops who occupied the town came from other parts of Bosnia and Herzegovina, like Bijeljina, and were joined by local people. Amir, emphasized many times "that was my neighbour". Or as Zijad said: "that was my work colleague". It was said that many people who were once friends appeared in the uniforms of enemy soldiers (although some Serbs helped non-Serbs in the occupied city).

On 30 April 1992, the two bridges linking Bosnia and Herzegovina to Croatia over the Sava River were bombed. ${ }^{5}$ After this, the non-Serbs who did not flee were imprisoned, beaten, raped, killed and taken to detention camps in the city and outside it. It became impossible for non-Serbs to live in Brčko during the war. In fact, after the end of 1992, few non-Serbs remained and the city became a Serbian city. ${ }^{6}$

Muslims and Croats fled especially to the South of Brčko, within the municipality of the same name, which would later be called the Brčko District.

Brčko was very important during the war. The Brčko corridor, also known as the Posavina corridor, became the main connection between the east of Bosnia and Herzegovina (along the Drina River, on the border with Serbia) and the west (near Banja Luka, the future capital of the Republika Srpska). Both regions were under the control of Serbian forces. This corridor also connected these regions to areas under Serbian control in Croatia.

Armed confrontation was constant along the corridor. Serbian forces fought to expand it while nonSerbian forces contained its expansion to the south and west, keeping it, between losses and gains, around four kilometres wide (Cf. Deronjić 2008; Farrand 2011). In Deronjić's words:

\footnotetext{
2 These reports are based on statements collected in Brčko in 2015. I would like to thank Fapesp for the grant offered for the postdoctoral research and the University of Banja Luka (Banja Luka, Bosnia and Herzegovina), which accepted me and made possible the realization of the field research.

3 The five SAOs (Srpske autonomne oblasti) established in 1991 in Bosnia and Herzegovina are: Romanija and Birač (capital Pale), Bosanska krajina (capital Banja Luka), Eastern Herzegovina (capital Trebinje), Semberija (capital Bijeljina) and Northern Bosnia-Herzegovina (capital Doboj) (Čekić 2005). In January 1992, these regions became known as the "The Serb Republic of Bosnia", and in the middle of 1992 it was renamed Republika Srpska.

4 According to Peres (2005: 102), at the end of 1991 a truce was established in Croatia, with Serbian forces holding $22 \%$ of Croatian territory, where blue helmets would supervise the ceasefire. This situation would continue until the second half of 1995 , with the retaking of these territories by the Croatian army (except Eastern Slavonia, reinstated in Croatia in 1997). See also: Security Council 1996; Grandits, Promitzer 2000; Peres 2010.

5 After the war, the bridge for cars and pedestrians was rebuilt, but the railroad bridge was not.

6 According to the 2013 census, the Brčko District (the city of Brčko and nearby villages) currently has 83,516 inhabitants (approximately $42.3 \%$ Bosniacs, $34.5 \%$ Serbs, $20.5 \%$ Croats, and 2.3\% who did not respond, did not want to declare themselves or are called others) (Popis 2016). According to the 1991 census (the previous one), the municipality had 87,627 inhabitants (approximately 44\% Muslims, 20\% Serbs, 25\% Croats, 10\% Yugoslavs and others) (Nacionalni 1991).

7 The term municipality (općina or opština) refers to an administrative region that in this case includes the city of Brčko (grad) and neighboring villages (selo).
} 
The position of the Brčko brigade is not a consequence of the city's strategic position, but a result of three and a half years of fighting against the Chetniks, ${ }^{8}$ which has led to a result of strategic importance. Brčko was and remained a "narrow throat" of the Serbian corridor, for which reason the Republika Srpska never managed to breathe with full lungs and, in the end, could not consolidate itself into a single piece [of territory] (2008: 147). ${ }^{9}$

Indeed, during the peace negotiations of 1995 (which led to the Dayton Agreement), no consensus was reached about Brčko. Acceptance of being encompassed by the Republika Srpska would signify an award for ethnic cleansing, given that the city had its non-Serbian population completely swept from the territory. It would also be a great defeat for those who had fought and died in clashes along the corridor. If it were encompassed by the Federation of Bosnia and Herzegovina (at times referred to here as the Federation), it would cut the Republika Srpska in half, making its territory discontinuous and rendering any peace agreement unfeasible at that time. Discussions concerning the municipality and any other solution for the region could jeopardize the commitment to peace. Therefore, the resolution of Brčko's situation was postponed and delegated to international arbitration. Finally, in 1999, a Final Award was issued that established the creation of the District as an autonomous and multiethnic region. ${ }^{10}$

Thereafter, the Brčko District would be a condominium of both entities under the jurisdiction of the central government of Bosnia and Herzegovina. It should be recalled that the peace agreement reached in Dayton (in the United States) recognized two Bosnian political-administrative regions, known as "entities": the Republika Srpska, with a majority Serb population, and the Federation of Bosnia and Herzegovina, with a majority Bosniac and Croat population. ${ }^{11}$

From 2000 to 2012, the District was under the administration of United Nations supervisors. ${ }^{12}$ In 2012, the closure of the supervisor's office indicated the official determination that the supervisor's presence was no longer needed, since the restructuring of the Brčko District had been successfully achieved, many former refugees had returned to the city and a multi-ethnic environment was created:

The Supervisor and his Office operated at the centre of Brcko's political and administrative life for more than 15 years, supporting refugee return and economic recovery and helping to establish multi-ethnic institutions and an integrated education system, among other achievements (Moore 2013: “online").

Transforming a Serbian city into a city for all the groups involved an international police and administrative effort, as well as massive investment in physical and political reconstruction of the space. According to Jeffrey, establishing a democratic government in Brčko was not necessarily achieved by democratic means (Jeffrey 2013: 87), since the supervisor had the power to impose and veto policies.

8 Chetnik (četnik) was the name of the Serbian political movement - and its armed forces - which during World War II worked for the restoration of the Serbian monarchy of the Kingdom of Yugoslavia. This term came to be reused during the conflicts of the 199os. In addition to denominating a paramilitary group led by Šešelj, it became associated to any Serbian paramilitary group, and is used until today, in a generic way, to designate any Serbian nationalist (Cf. Glenny 1996: 295 apud Peres 2005: 99).

9 Translated from the original to Portuguese by the author.

10 The term "multiethnic" is the one preferred in the English-language literature, especially in the documents and treaties on the founding of the District. Despite this, I will often use the term "multinational”, which I prefer, because it refers to the so-called "national groups" of Bosnia and Herzegovina. Even locally, a change can be noticed in the vocabulary used to define the referred groups, who had previously been commonly referred to as national, and now as ethnic (although they are still defined as "constituent nations" in the Constitution of Bosnia and Herzegovina, that is Annex 4 of the Dayton Agreement). This change points to the process of establishing what are now considered "cultural" or "ethnic" boundaries between these groups and to the essentialization of differences between them, leading to the establishment of new categories of representation of political subjects and political affairs. On the change in the post-socialism vocabulary and its implications, see Peres (2005).

11 The Constitution of Bosnia and Herzegovina, or Annex 4 of the Dayton Agreement, establishes the two entities, recognizes three constitutive nations, Bosniac, Serb and Croat (other national groups, "minorities" or "ethnic groups" are joined, not explicitly, in one category called "others") and the Serbian, Croatian and Bosnian languages (Cf. Constitution 1995). It should be noted that before the war, they were all the same language that then earned national denominations, as I will detail later.

12 International supervision in Brčko was established in the First Arbitration Award issued in February 1997. The first supervisor was Robert Farrand, who was sworn in shortly afterwards. The Final Award, which established the District, was only issued in 1999 and the District foundation was formalized in March 2000. About these early years, see Farrand (2011). 
Jeffrey also affirms that the effort was based mainly on the "symbolic neutralization" of the various groups in the city, which can be seen in the new model of identity cards, ${ }^{13}$ new street names - most of which are named after non-controversial writers, and not politicians or war heroes - and in the common use of Latin alphabets (common among Bosniacs and Croats) and Cyrillic alphabets (common among Serbs), among other things. According to the annex to the Final Award:

The District Assembly shall determine all symbols for the District, provided that all such symbols shall be politically and ethnically neutral and subject to final approval by the Supervisor. There shall be no flag for the District other than the flag of Bosnia and Herzegovina. The flags of both entities may be flown within the District, but only together with the $\mathrm{BiH}^{14}$ flag. The flag of one entity will not be flown without the other being flown on essentially equal terms. Both the Latinic and Cyrillic alphabets will be used on essentially equal terms for all official purposes. Any resident of the District shall have the right to request the issuance of official documents in any of the three officially-recognized languages and shall have the right to use any such language in official and all other correspondence (Osnovni 2009).

However, this process of equalization / neutralization of the groups in the city, which is explained in the quotation above, did not occur without impasses, violence and protests: students protested against the unification of schools, the first Bosniac mayor was greeted with stones, recently rebuilt houses were burned, etc. Nevertheless, during the first years, and under the supervision of the UN, much was done. The municipality / District was rebuilt, streets were renamed, a unified educational system was put in place, Bosniacs and Croats got their houses and apartments back, new Serbian inhabitants moving from different areas of the Federation and Croatia received a whole neighborhood to build their homes. There was a clear effort to build a common space for all.

In any case, when one is living there it is possible to perceive a barrier, according to which each person knows very well to which group they belong and what this means. In this sense, it can be said that from the hectic beginning, until 2015, things have normalized.

So what does it mean to build a post-war multiethnic city?

\section{The bridge}

The socialist state of Yugoslavia as a whole was also conceived as a means to fight against nationalism by creating a balance of power between the nations and nationalities that composed it. It was a response to the clashes and confrontations that devastated the country during World War II, which particularly opposed Serbs and Croats, and which at the same time united all the different groups in the partisan fight against fascism. Despite the apparent similarity to what is being attempted to construct in Brčko, that is, a multinational place, in the former Yugoslavia, national distinctions were noticeable in a different way. For instance, religion belonged to the sphere of private life; the main focus of interest of public policies was

13 This decision was essential to enable the non-Serbian refugees to return to their homes in the city, since the Republika Srpska was initially responsible for issuing the identification document in Brčko (Cf. Farrand 2011). It was only in 2006 that the District assumed all its legal responsibilities, and the interentity border separating the northern part and the city of Brčko - belonging to Republika Srpska - and the southern part - belonging to the Federation - was definitively abolished. However, since 2012, the renewal of identity cards in Brčko requires the declaration of the entity of the citizenship. This requirement is related to the electoral law, which determines that for the tri-national presidency and parliament of Bosnia and Herzegovina, the Federation is responsible for the election of Bosniac and Croatian representatives and the Republika Srpska for the Serbian representatives. Therefore, although they live in the same multiethnic district under the jurisdiction of the local (District's) and the central governments (Bosnia and Herzegovina), without an adscription of belonging to one or another entity, citizens of Brčko cannot renew their documents or vote in the general elections. Choosing a citizenship entity is not always simple; a friend of mine, for example, who is the daughter of a Serbian mother and a Bosniac father - who never thought of himself in these terms - now defines herself as a Bosniac of the Federation, like her father; but her brother, as well as her mother, defines himself as Serb from the Republika Srpska. When she explained this to me, she asked "imagine if there is war again?", with a nervous laugh (verbal information). On this subject, see also Pašalić 2016.

14 Abbreviation for Bosna i Hercegovina (Bosnia and Herzegovina). 
the working class; and people were first considered colleagues or neighbors, and not as members of one or another national group. National differences were not negated, but were known, shared and in certain moments celebrated, ${ }^{15}$ without becoming an issue. Phrases like "we were all mixed", "it didn't matter who was who" or "we were all neighbors" are commonly heard until today in Bosnia and Herzegovina to describe that period and how the wars of the 199os caused surprise for many people.

In a conversation with Siniša Kisić, the first mayor of Brčko after the establishment of the District, he described life before the war as good: "people used to go to Ficibajer" (a recreational area by the river) - "it was better than the beach! - we used to have picnics, barbecue... there were restaurants and a pool with a diving-board by the Sava River", and "we used to swim to the other shore [in Croatia] to pick corn and roast it on this side. There was social security, a certain insouciance in that system, it was good." (verbal information). ${ }^{16}$

Today no one swims in the Sava River. There are few boats on its banks and they are forbidden to dock on the other side, since the Sava became the border with Croatia. It is still possible to walk along its banks, but the atmosphere is different from that described by Kisić, there are fewer cafes and restaurants, and less people.

On the other side of the Sava, in Croatia, there is a small village called Gunja, which in the past participated in life in Brčko, where many of the residents came from. Not anymore. There are border checkpoints on both sides of the bridge and, since Croatia became part of the European Union, a passport is required to cross them. Few residents have a passport. Few residents of Brčko or Gunja are wealthy enough to afford one.

Brčko was an important economic and industrial center before the war, ${ }^{17}$ but no longer. Many people do not have a job. Things improved a little when the District was created, but then got worse again, people say. Having coffee in the city center is one of the most popular activities. From time to time there is a festival, when people may go to the theater, cinema or a music concert; some take place outdoors in the city center and some in the city's cultural center.

Everything changed when the bridge was blown up.

In Brčko, the date that marks the beginning of the war was 30 April 1992, when the bridges over the Sava River were destroyed. No one died on the railroad bridge. What happened on the other, which was used by pedestrians, cars and buses is more controversial.

Every year, on 30 April, hundreds of people go to the bridge to pay tribute to those who died in its bombardment. It is said that over a hundred people, either coming from Croatia for May Day celebrations or going to Croatia fleeing from the war that had already started in other parts of Bosnia and Herzegovina, were on the bridge when it exploded. However, it is not known who exactly was there and who was killed in the explosion: they were not from Brčko. I was told that body parts flew over the city that day.

At the commemoration of 30 April, flowers are thrown into the river and people walk in silence to honor the victims. The ceremony lasts two days: on 30 April it is held at the bridge; and on 2 May, the pedestrian mall is lined with photos of the war and speeches are given at the monument of the Army of Bosnia and Herzegovina (in front of the Hotel Posavina and the Police Office), at the former Partisan Sports Centre

\footnotetext{
15 In addition to folklore, which was incorporated and celebrated through the language of the state, nationalities in the former Yugoslavia, according to Bringa (1995), were linked to a universe of practices and customs, which, in the case of the Muslims, defined them as a group and as a group who differed from Catholics and Orthodox Christians. According to this author, deep bonds of neighborliness were verified, and become real in daily (and secular) practices such as being friends, having coffee together, greeting each other on religious holidays, etc. These were moments when people referred to their differences. The presence of the other group, Bringa affirmed, was fundamental in the construction of the identities and the essence of being Bosnian (Bosanac) was to grow in this multiethnic and plural milieu (1993: 120). (see Peres 2010: 271).

16 Interview held in Brčko on July 24, 2015.

17 Being also a rail, fluvial and road communication axis. Remaining only the last of them.
} 
(DTV Partizan) and at the wharf and warehouses of the transportation and distribution company Luka by the river. All of these places had served as detention centers and death camps for non-Serbs, especially at the beginning of the war. The Luka camp was closed in June 1992, when, according to reports, the remaining detainees were taken to the forced labor camp in Batković, near Bijeljina (under the command of Serbian forces)..$^{18}$

Nevertheless, according to Ranko, a Serbian interlocutor who arrived in the city during the war, no one knows who, if anyone, died in the bridge explosion. He implied to me that Muslims talk too much and lie. Also in Brčko, as it has been noted in relation to the Federation of Bosnia and Herzegovina and the Republika Srpska (Cf. Peres 2013), there are at least two stories: one that is told by non-Serbs and another that is told or silenced in Brčko by Serbs, since the first story narrates the aggression caused by the latter, most of them accomplices, or also refugees. Thus, the most that many Serbs I spoke to in Brčko were able to say about the war is that they were also victims. And in this post-conflict context, the victims are the new heroes. The new flags raised in their names are like a war cry. Since they are living proofs that the other was the aggressor, all pain suffered by a victim easily becomes an offence to the other. The other here, although many times depicted as soldiers who committed atrocities, is commonly identified as a member of a national group, who committed crimes or who denied and still denies that crimes had been committed.

In this context, what multiethnic district was built?

\section{For human rights: monuments and schools}

Hannah Arendt, in "The Decline of the Nation-State and the End of the Rights of Man", discusses, among other things, the identity between human rights and national sovereignty (1989:305), which the Universal Declaration of Human Rights of 1948 also emphasizes, by pointing to the right to nationality. ${ }^{19} \mathrm{At}$ the time she was writing, the state had ceased to be an instrument of the law to become an instrument of the nation (idem: 309), and in this sense true freedom would only be possible with national emancipation (idem: 305). Arendt was concerned with the horde of stateless people and refugees that resulted from the post-World War I treaties and which increased after World War II. The problem for these populations was and still is evident today, considering the millions of refugees without at least the right to asylum, a right which is also included in the 1948 Declaration. It is a population that nobody knows exactly what to do with, which is relegated to refugee camps, or even to detention camps, or which is condemned to live anonymously and illegally in other countries. ${ }^{20}$

As we will see in this article, the Dayton Agreement constitutionally produced the status of "nonnational" in the name of human rights or, in other words, in the name of the right to difference and recognition, and in the name of multiculturalism. By being normatively based on the understanding that a citizen is a member of a constituent national group (Serb, Croat or Bosniac), politics, the school system and urban space also produce exclusion and displacement of the constituent nations belonging to another entity, ${ }^{21}$ and of minority groups, people born from mixed marriages, those who claim Bosnian nationality

\footnotetext{
18 As for the remaining non-Serbs in the city, they were finally imprisoned or killed or exchanged in late 1992 for Serbs who had been imprisoned when Bukvik, a village in the municipality of Brčko, was taken over by Bosnian forces. According to Deronjić (2008: 77-78), Croats and Muslims formed Brčko's 108th Brigade of Bosnian forces. In February 1993 this brigade was formally divided into two brigades (that continued to fight together): Brčko's 108th Motorized Brigade of the Bosnian-Herzegovinian Army (Armija BiH) - later renamed the 205th Cavalry Brigade -, and Brčko's 108th Infantry Brigade of the Croatian Defense Council (HVO).

19 Article XV. Everyone has the right to a nationality (Declaration 2009).

20 On this subject, see Agier (2011).

21 Of Bosniacs and Croats in the Republika Srpska and of Serbs in the Federation.
} 
(which does not exist constitutionally), or people who refuse the recognized national identifications: the state does not represent them, since there is no available representation for them established by the Constitution of this state.

I will return to this issue, but first we should ask how are those constituent nations, which have the right to representation, represented?

As mentioned before, an effort was made to construct Brčko as a multinational place where the differences between the groups - in this case Serbs, Croats and Bosniacs - would be respected and neutralized. The term "neutralized" refers, however, not to the annulment of diacritical signs of difference, but to their equitable presence in the District, a fact that emphasizes the right to difference - the implicit logic is that, if the presence is equitable, it is not offensive. This policy is visible in public space, felt in daily life and tacitly present, given that since the end of the war, belonging to a national group in Bosnia and Herzegovina concerns an entire universe of ways of thinking and narrating what happened, which, in accordance with the policy of building this multi-ethnic space, must also be respected. As Taylor (1994: 25) points out, "Nonrecognition or misrecognition can inflict harm, can be a form of oppression, imprisoning someone in a false, distorted, and reduced mode of being". The politics of difference, according to this author, would thus be those demands for recognition that are based on the supposed relation between recognition and identity, with this referring to how a person defines oneself, his or her fundamental characteristics as a human being ${ }^{22}$ (ibid .: 25). Therefore, these are the two main lines that will be analyzed here: one which refers to recognition and the other related to the construction of identity and its authenticity. Firstly, regarding the construction of monuments in Brčko, and later, regarding the school system.

\section{Monuments}

Soon after the beginning of the war in Brčko in 1992, a monument to Draža Mihailović was erected in the center of the city, in front of the city library, which is now called the National Library of Brčko. Draža Mihailović was a Chetnik leader imprisoned and killed by the partisans ${ }^{23}$ after their victory against fascism (here represented by the Axis, particularly the Nazi regime, by the Chetniks, a movement formed basically by Serbs, and by the Ustashas, ${ }^{24}$ a movement formed mainly by Croats). The entire history of socialist Yugoslavia was built upon the "fight and victory against fascism" and on the idea of "brotherhood and unity" among the national groups (represented by their own Republic) and nationalities (those groups without their own Republic) of the former Yugoslavia. In this sense, Mihailović oscillated between being considered a criminal - a fascist, bloodthirsty - and a hero, a defender of the Serbs. The war of the 1990s revised the Chetnik movement, which was inspired by the hero Mihailović, long before his rehabilitation in 2015.

On the occasion of the declaration of the multinational district, this and other monuments had to be removed. Mihailović's was moved to the nearby Orthodox cemetery (photo 1). No agreement was reached about the removal of a monument located downtown next to the Hotel Jelena, called "the monument to the Serbian forces who liberated Brčko" (photo 2). Therefore, the erection of three other monuments was established by the UN supervisor for Brčko: one to the Army of Bosnia and Herzegovina and its local

\footnotetext{
22 Appiah (1996) defines in this same line the policies of recognition, as those based on the field of the authenticity of the identity. However, this is usually forged, according to him, into essentialisms and monologisms.

23 Mihailović was captured, tried and executed in 1946, when he also lost all of his civil rights. In May 2015 his rights were restored in Serbia, that is to say, his descendants had the restitution of the real estate and properties previously in his name. (Cf. Cvijić 2015)

24 The Ustasha Nationalist Movement (ustaša) was created in 1929 by Ante Pavelić, future leader of the Independent State of Croatia (NDH), founded during World War II and allied to the Nazi regime. The term came into vogue again during the war of the 199os, to designate any Croatian nationalist.
} 
brigade (photo 4), another to the Croatian armed forces and its local brigade (photo 3), and another to civilians killed in the wars in Brčko (in World War II and the 199os war). The first two were erected in 2011, the latter was embargoed by local political forces (Cf. Pao 2013).

Photo 1: Monument to Draža Mihailović in the Orthodox cemetery of Brčko 25

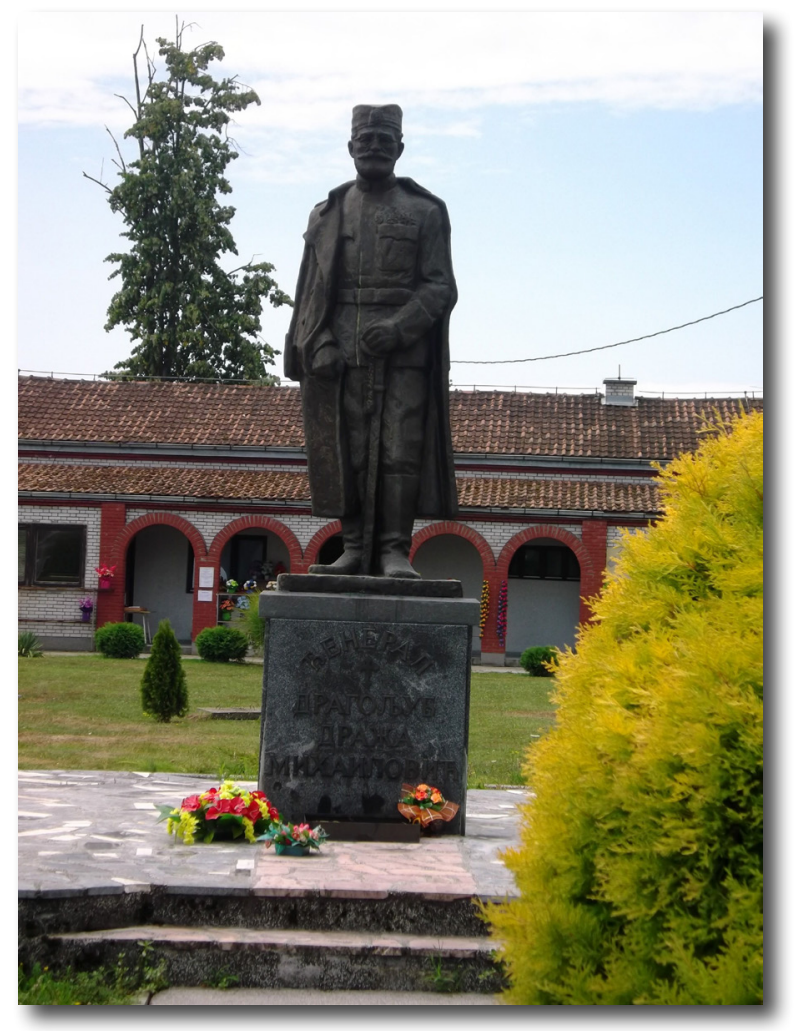

In any case, these three monuments located in the center of the city constitute a very concrete and visible example of the presence of the three national groups in Brčko, represented here by their armed forces and mounted no more than 100 meters from each other. The first, placed in honor of the Serbian forces (VRS), "who liberated Brčko"; 26 the second built in homage to the soldiers of the Croatian forces (HVO), "who died defending Brčko" ${ }^{27}$; and the third in honor of the Bosnian forces (ABiH) and their soldiers, "who fought and died for Brčko"28. 
Photo 2: Monument to VRS

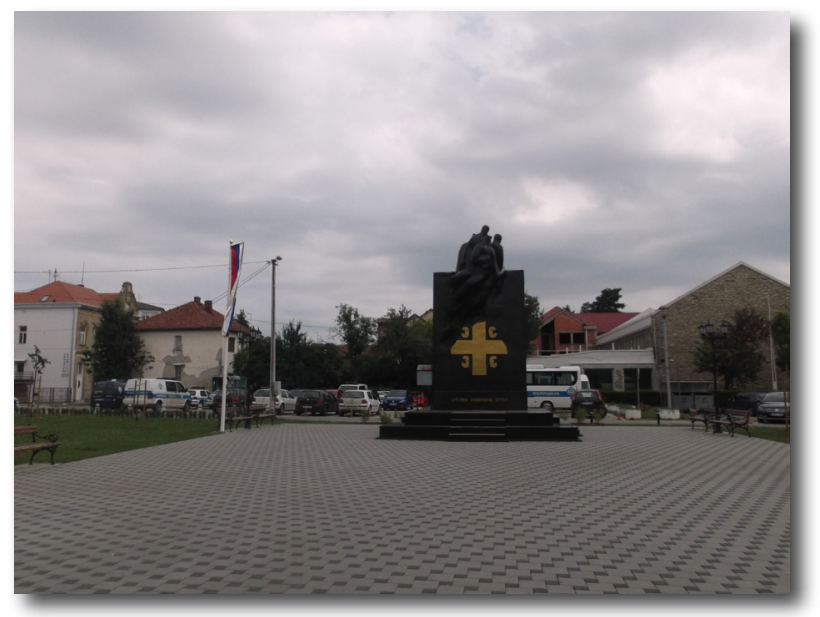

Photo 3: Monument to HVO

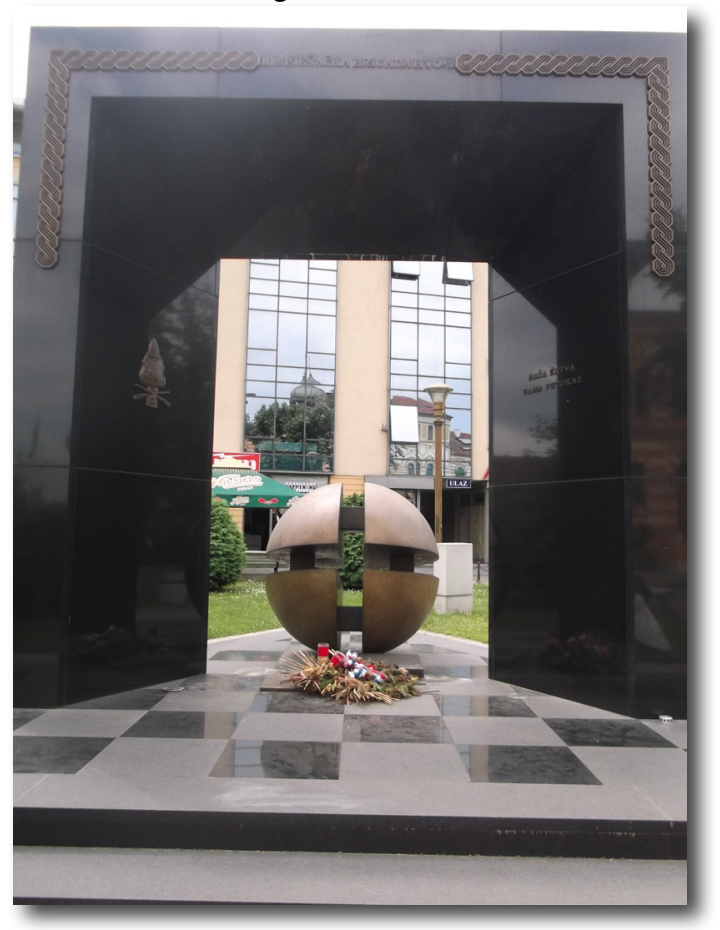

Photo 4: Monument to $\mathrm{ABiH}$

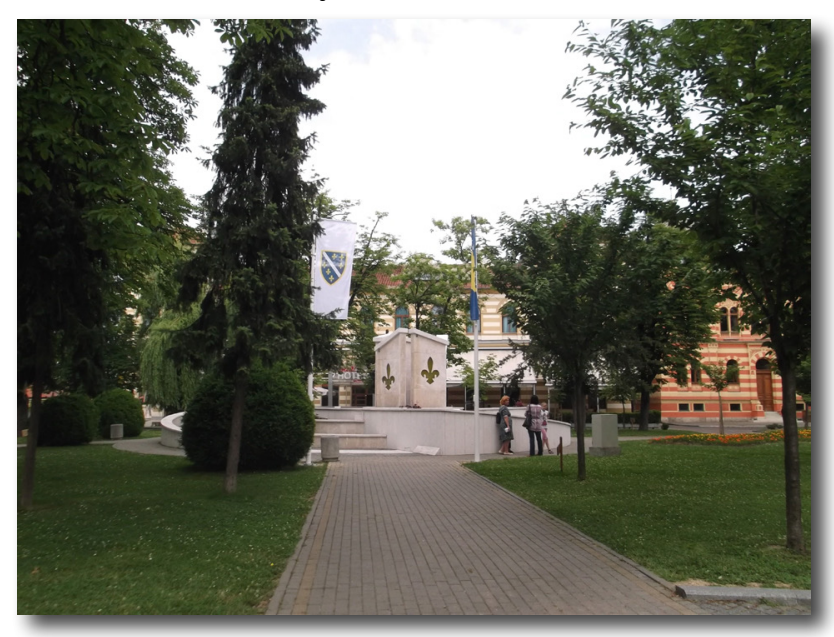


Enes Pašalić, a sociologist and politician from Brčko, wrote an interesting article on the monuments of the city that presents the resolutions issued by Brčko's UN Supervisor Raffi Gregorian (from 2003 and 2009) that determined the construction of these three new monuments. He raises the absurdity of both building a neutral monument to victims of the wars, in which neither names nor perpetrators would be highlighted, as well as having three military monuments in a single city. In his words:

Both the monument to those who fought for Herceg-Bosna ${ }^{29}$, and the one for those who fought for a Serbian Brčko, exclude a monument to those who fought for an integral Bosnia and Herzegovina. The difference between them is contradictory and can only be justified by the extermination or destruction of the other, considered as their own negation (Pašalić 2009: 60). ${ }^{30}$

Regarding the embargoed monument to the civil victims of the wars - a neutral monument with no names - Pašalić argues that it would be a great historical forgery, since the victims of the 1990s war in Brčko are non-Serbs, being mainly Bosniacs / Muslims. And to ignore this fact is to ignore that the victims actually died only because they belonged to a specific national group (ibidem: 61 ). $\cdot^{11}$

The erection of these military monuments is a paradigmatic example of the policies favoring the equal rights to the culture and expressions of national groups in Brčko, since the neutrality of the groups is here perceived as the right to equal representation. It does not matter that the representation of one group, in the final analysis, to agree with Pašalić, signifies the annulment or destruction of the other. That is, each national symbol - or monument - does not represent only itself, but is also offensive to the others. Moreover, in addition to presenting opposing armed forces, their equal representation in public space would be saying that what happened in Brčko was a civil war, an interpretation that goes against the Bosniac narratives which affirm that what happened in Bosnia and Herzegovina was in reality an aggression.

Therefore, if the establishment of a multinational political space in Brčko presupposes respect for differences and if we take seriously the demands for recognition, the question that remains is: what kind of respect ${ }^{32}$ was erected in this city by these monuments and what kind of difference is this that is sustained by an act of war?

\section{Educate for the nation: what nation?}

Issues concerning the equalization of rights, as seen in the case of monuments, are frequently present in all spheres of public life in Bosnia and Herzegovina, especially in Brčko where policies are focused on the construction of a multinational space.

\footnotetext{
29 This is a Croatian region proclaimed in Bosnia and Herzegovina during the war. Herzegovina is the southern region of Bosnia and Herzegovina, with no national connotation, despite having historically more homogeneous regions with Croatian or Serbian majority. According to Deronjić (2008), Muslims and Croats fought together in Brčko, despite having fought against each other, especially in Central Bosnia and Herzegovina, between 1993 and 1994 . Therefore, it cannot be said that this monument would represent only those who acted in the separatist movement for Herceg-Bosna. Nevertheless, both the monuments and the policies in Brčko tell a story in which there is little space for contradictions or nuances.

30 Translated from the original to Portuguese by the author.

31 About the memorials to victims in Brčko, there is a plaque on the bridge over the Sava River in honor of the "Serbian, Roma, Jewish victims and the supporters of the national liberation fight (partisan) belonging to other nations and nationalities in World War II, killed by the Ustashas and the Germans", and another in honor of the Jews of Brčko or those Jews who took refuge there, who were killed on 10 and 17 December 1941. At one of the warehouses of the Luka Company wharf, which has been transformed into a war memorial (spomen soba), there is a plaque that points out that innocent Croatian and Bosniac civilians were killed there, but does not mention perpetrators. Only the first two are in a public space, they predate the war of the 199os and refer to World War II. The third is at a wharf, which belongs to a private company, and for that reason is closed to the public. This is only accessible on May 2 , when there is a ceremony in the city, or in a monitored visit to the memorial, which remains closed to the public on other occasions.

32 On the moral conflict about shared contexts of respect and disrespect and the constitution of political units based on the alterity relations erected in this practical-discursive field, see Montero, Arruti, Pompa (2011).
} 
In this sense, in the name of human rights, which are understood here as the rights of each group to its own culture, language and education, and considering that school is the privileged place where these elements are taught and learned, no common national school curriculum has been established in Bosnia and Herzegovina. Each entity and the Brčko District have their own Curricular Parameter, or "Educational Plan and Program" (Nastavni plan i program), to be applied in schools, which specify what and how to teach each year in every subject. ${ }^{33}$

In general, these programs are similar, but in the Republika Srpska, children learn Serbian History, Geography, Language, Music and Religion. In the Federation of Bosnia and Herzegovina children learn Croatian or Bosnian History, Geography, Language, Music and Religion. These subjects compose the so called "subjects of national contents". In the Republika Srpska and in the Federation of Bosnia and Herzegovina they must respect the majority national group (except when there is no significant majority) ${ }^{34}$, and in the Brčko District, they must respect all three of them.

This does not happen without dispute, as we will see. Moreover, according to a study of the textbooks that present the subjects of national content currently used in Bosnia and Herzegovina (Obrazovanje 2007), none of them is free of discriminatory content in relation to other groups. The educational materials either ignore the other groups or treat them as inferior.

Before entering the field of disputes and dystopias in relation to this educational system, it is appropriate to approach the problematic issues in some of these disciplines.

\section{Teaching of national subjects: language, history and geography}

\section{Mother tongue?}

In regard to this issue, the first question is: What happened to the common language that everyone spoke and learned in the past? This was the naive and provocative question I asked the director of the Pedagogical Institute of Brčko. ${ }^{35}$ He replied that during the period of the former Yugoslavia, there was a commitment to Serbo-Croatian / Croatian-Serbian language. With the disintegration of Yugoslavia, each group began to speak their own language. According to the director, the name of the language derives from the name of the nation - Serbs like him, call it Serbian, Croats call it Croatian, and Bosniacs call it Bosnian - given that the issue is related to human rights and to the right of each national group to be taught in its own language. Therefore, the recognition or not of the three languages in Bosnia and Herzegovina is also a matter of human rights.

During the years of the former Yugoslavia, in Bosnia and Herzegovina, as well as in Serbia, Croatia and Montenegro, the mother tongue was Serbo-Croatian, or Croatian-Serbian, which was written in two alphabets, Latin and Cyrillic. The wars of the 199os gave rise in Bosnia and Herzegovina to the three languages recognized in the peace agreement: Bosnian, Serbian and Croatian. These three are based not only on the same language but also on the same dialect of this language, whose variants do not necessarily follow the boundary lines between the states and, much less, between groups in a single region.

\footnotetext{
33 Education - primary and secondary - is public and compulsory in Bosnia and Herzegovina. There are no private schools, only in kindergarten and higher education.

34 The so-called "two schools under one roof" policy will be treated later on in this article.

35 Interview with Slobodan Ristić (director of the institute) and Ferhid Halilović (a teacher) at the Brčko's Pedagogical Institute on 27 May 2015 . The interview would be only with Ristić, but he insisted on the participation of his Bosniac colleague.
} 
The differences between them had to be created, and this was done primarily by naming them. Secondly, it was done, and still is done, through literature, lexical differences - words - as well as the alphabet and, of course, the learning and teaching of the languages.

If they are the same language, what makes them different? The Serbian language is the language spoken by the Serbs and is characterized by the use of the Cyrillic alphabet. The Bosnian language is the language spoken by the Bosniacs, but also by many others from Bosnia and Herzegovina who prefer to use this name for their language. It uses the Latin alphabet and has words derived from Turkish (which is also very common in Serbia). The Croatian language is the language spoken by Croats; it uses the Latin alphabet and is characterised, among other things, by a certain purism, that is to say, by not using words considered new incorporations to the language, foreign, loanwords or more specifically Latinisms, Anglicisms, Turkicisms, etc.

Since the war, there has been a reinvention of the language, and what was once perceived as a single language may now be recognized as Serbian, Croatian or Bosnian, depending on particular details. For example, many Muslim greetings, of Arab or Turkish origin, became part of the common vocabulary in Sarajevo during the war, ${ }^{36}$ in addition to the increasing use of the aspirated $h$, in the middle and beginning of words ${ }^{37}$ Nevertheless, the novelties in the language and even its names are usually presented as elements that were old and that had been repressed over time.

The denial of the language of the other, thus conforms with the creation of one's own language, since these languages are only different according to differences created or deepened between one's own language and the language of the other. Despite this, these languages, when not called Serbian, Croatian or Bosnian, are seen as a single language and given the name s-c-b ${ }^{38}$ or simply referred to as naš (ours).

Therefore, if in practice it sounds as if a single language is used, it officially seems as if everybody is multilingual. Web pages of official government agencies, for example, present versions in the three languages; curricula, in the field of language, present, among other languages, these three; language and literature textbooks are presented in the three languages as well.

Language is now one of the major issues related to respect for national differences in Bosnia and Herzegovina and the basis for the claims when those rights are not met. Furthermore, there is no teaching of national language apart from the teaching of national literature. For this purpose, from a common range of great writers who wrote in Serbo-Croatian, those considered Serbs, Croats or Bosniacs were separated and classified respectively as writers who wrote in Serbian, Croatian or Bosnian. The reading of these authors, especially in the school environment, is thus intended to affirm the nationality of the group concerned, ignoring or subjugating the other groups, and where possible, stressing the linguistic differences (Cf. Veličković 2015).

\section{History}

In relation to the teaching of history, many say that this topic is inoffensive since contemporary history is not studied at school (and it is recognized that there is no consensus about the reasons for the wars of the 199os). Nevertheless, it is taught that the nationalities have existed since time immemorial, and therefore the veracity of the peoples and their respective languages. In addition, there is space for totally different

\footnotetext{
36 Cf. Armakolas 2007; Maček 2007, 2009; Veličković 2006.

37 The aspirated $h$ of the language (as in lahko / lako, easy, kahva / kafa / kava, coffee) is considered to be an unstable sound that is not heard or pronounced, and which over time has been eliminated or replaced by other sounds or letters. Its conservation (or rehabilitation) among Muslims can be explained by the common use of this sound in the Arabic language and in the Koran, hence, by the fact that they are more accustomed to pronouncing it. Cf. Zlotrg, Vuković 2016: 29-32.

38 Or shb, srpski-hrvatski-bosanski (Serbian-Croatian-Bosnian)
} 
interpretations of the Middle Ages, the Ottoman period, the Serbian insurrections of the nineteenth century, the assassination of Archduke Franz Ferdinand by Gavrilo Princip and the beginning of World War I, about World War II and the Partisan victory, the socialist regime and the former Yugoslavia, etc.

In this sense, all of Bosnian-Herzegovinian history is open for interpretations that may favour a particular group, and this is reflected in how and what children are taught at school.

\section{Geography}

In geography what comes into question are the borders and the natural beauty of the nation, described in each program in a different way, and which refer to a certain territory and people. These are finally drawn on the walls of the school in a certain language, which can be identified by the alphabet, by one or another word that marks a national identity, or by the map of Bosnia and Herzegovina, presented as a whole or divided by the borders between the entities.

\section{Discrimination}

Considering this presentation, in some parts of the Republika Srpska there is a Bosniac population that is side-lined, disadvantaged and discriminated, because they are not allowed to follow their own school curriculum. In the Federation, a similar problem is faced, as well as the fact that in areas where there are Bosniac and Croat populations, there are the so-called "two schools under one roof": in one period Croat children learn Croatian subjects, in another period, Bosniac children learn Bosnian subjects.

In 2013, parents of Bosniac children from two villages in the Republika Srpska ${ }^{39}$ went on strike and stopped sending their children to school. They set up a camp in front of the office of the UN High Representative in Sarajevo to demand a resolution on the teaching of subjects of national contents at schools in the Republika Srpska. ${ }^{40}$ They criticized the fact that few teachers and no principal were Bosniacs and that their children were being taught to read and write in Serbian, which, in the case of small children, would not be a problem if the use of the Cyrillic alphabet by itself was not offensive.

I regularly heard comments in Sarajevo about the absurdity of the "two schools under one roof" system in some cities of the Federation, which is seen as a form of segregation, as fuel for the perpetuation of division, and as an obstacle to reconciliation. This uneasiness refers to the understanding that children should not be treated as ethnic-national beings, which contrasts with the universal perception of the subject, especially concerning children. Any similarity, however, between these schools and the demands for schools like these in the Republika Srpska did not seem to exist for my interlocutors who shared the distress of those parents who did not have their rights guaranteed in the Republika Srpska.

In fact, the controversy surrounding these issues is especially linked to the lack of trust in relation to how institutions are organized and make themselves present in people's lives since the war.

The problem has not been resolved until today, even the Minister of Education and Culture of the Republika Srpska, who in 2015 authorized not teaching the Bosnian language, but "the language of the Bosniacs". This was obviously rejected and seen as a provocation, since the name of the language is Bosnian and not Bosniac.

\footnotetext{
39 Konjević Polje and Vrbanjci.

40 The UN High Representative for Bosnia and Herzegovina would be the only one who could overrule various government bodies to resolve the issue. It should also be noted that there is no Ministry of Education within the central government, each entity has its own ministry with its own minister (in Brčko, there is no ministry, but a Secretariat of Education).
} 


\section{Brčko: common curriculum program and divided blackboards}

Nevertheless, in the Brčko District the problem seems to have been solved.

During the war, it is important to stress, Serbian schooling was instituted in the city of Brčko; in Gornji Rahić and other villages of the municipality under Bosnian rule, Bosnian schooling was instituted; and in the Croatian parts of the municipality, Croatian schooling. The consolidation of the District entailed the unification of these regions and of the school system. The unification of schools resulted in the development of a single curriculum for the District. From then on, regardless of their national affiliation, students attended the same school, in which each group would have its specificities respected, especially its language.

How does it work?

Firstly, it was agreed that principals and teachers should be from all national groups regardless of the majority group from the area.

Since each group should have its rights respected, during the early grades, the blackboard is literally divided into two or three - depending on whether there are children from the three constituent nationalities. In the first column some children learn to read and write in their own language, in the second, other children learn in another language, and in the third, yet another: Serbian, Bosnian and Croatian.

When I asked Amira, a teacher, how a small child knew which language to learn, she explained to me that she usually arranges the desks in rows and orients each child to look at her or his side of the blackboard. In the third grade, children learn the other script - given that the basic difference at this point is between Latin and Cyrillic alphabets - so she inverts the desks or the columns on the blackboard. And in the fourth grade, each week, they have classes in a different script.

According to Amira, the contents of her classes when it comes to the teaching of language is basically the same, the only difference is the alphabet. Considering that the content is the same, I asked her if she did not waste a lot of time writing the same thing two or three times, which means that the children would have half a lesson, or a third of a lesson, depending on the ethnic-national configuration of the class. She answered yes, "but that this is the way things must be done". "Do the parents know about this?" I asked. "Yes, they are the first to demand that their children be taught in their mother tongue," she answered (verbal information).41

From the fifth grade onwards, children are separated in the language and literature classes, and in the religion classes. In high school, they are also separated, and these are indeed mixed schools, not organized by neighborhood, many of which are mono-national.

Regarding textbooks, since Brčko does not have its own publisher, they use textbooks from the Republika Srpska and the Federation which were drafted according to their respective educational programs. In elementary school, the government gives each child the textbook of her or his own national group; in high school, the students can choose, except for language and religion.

It seemed to me to be an idiosyncratic system.

First, elementary school teachers must work extra hard, given that they have to teach three linguistic versions of the same subject, even if they are practically the same. At the high school level in particular, teachers must know most of the books that young people can use and should think about how to teach some subjects in an appropriate and non-offensive way. Until the fifth grade, teachers must teach in each of the "three languages." After fifth grade and through high school, teachers can teach in the "language" of their choice.

41 In conversations with the author during the field research in Brčko, in 2015. 
I asked high school students what they thought of this system. Many said it was very good. And some said it was funny, "we talk to each other all day long, we attend the same classes and then during 'MotherTongue' lessons we have to be split into different groups as if we spoke different languages," Sabina replied.

In Amira's fourth grade elementary school class that I attended, she spoke in only one language to announce the children's grades for their language classes: "Nikola, Serbian language, 4. Amra, Bosnian language, 4." This sounded like a farce to me, for some it is funny, and for most it is just natural.

This school system, in turn, is often praised by scholars of Bosnia and Herzegovina, since it does not divide the students, while respecting their rights (Cf. Na torove 2015).

In a report to the UN on Bosnia and Herzegovina, Farida Shaheed, UN special correspondent in the field of cultural rights, ${ }^{42}$ states:

The over-emphasizing of cultural differences, including linguistic differences, is used to justify practices that enforce the segregation of students based on ethno-national affiliation. The Special Rapporteur stresses that this is a serious misinterpretation of cultural rights ${ }^{43}$, which must not be used under any circumstances to justify segregation policies (2014: 9).

In the same document, Shaheed points out the problems of both "two schools under one roof" and of mono-ethnic / mono-national schools. According to her, both have a rigid division of the school curriculums. In this sense, Brčko's example seems to be the best:

The system put in place in Brčko is often presented as a good model of integrated schools, ${ }^{44}$ where the pupils from different communities attend school together and mainly receive instruction in their own languages in the same classroom. [...] The law stipulates that students have the freedom to express themselves in their own language, and that school documents are to be issued in the language and alphabet requested by a student or parent. In class, only the blackboard is divided, enabling teachers to use both the Latin and Cyrillic scripts and to show the differences existing between the various languages (2014: 12).

Although, she seems to find that the problem persists:

Although the common core curriculum is better developed in Brčko, culture, language and history remain highly sensitive issues; officials there reported that they exercised caution "to preserve the different characteristics of groups, while bringing them round to universal values". [...] The Brčko District authorities do not view their system as ideal, and are making efforts to improve it. Teachers confirmed that progress in integration was not satisfactory (idem: 13).

In one way or another, by attending the same schools, children and young people do get to know each other, friendships are created, there is some dating. In fact, they learn that despite differences, the other does not necessarily represent a threat. But, what happens after class? They go back to their homes and neighborhoods, often walking past the monuments. In these domestic spaces many are regularly informed about the group they belong to. When it is time to go to university, Brčko does not offer many options: Bosniacs usually go to Tuzla in the Federation to continue their studies, Croats go to Mostar, the most important city of the Federation for Croats, and Serbs go to Banja Luka, capital of the Republika Srpska.

42 I am very grateful to Nenad Veličković for pointing out this UN report, which was reviewed in the magazine Školegijum (Na torove 2015). In this document, Farida Shaheed discusses several problems concerning the politics of difference and their abuses in Bosnia and Herzegovina, referring to many aspects I have addressed here and elsewhere.

43 According to this document, cultural rights refer to: "the right of each person to manifest her/his own identity, to participate (or not) in particular aspects of cultural life, and to have access to one's own cultural heritage, as well as that of others” (2014: 6), without any obstacle or fear (idem: 1).

44 In the document, it is not explicit who considers Brčko's system a good model. 
They also usually do not go to the same cafes in the city. Life teaches them which group they belong to and school constantly reminds them of this, by separating them in different groups for classes of national contents subjects: from an early age, when the blackboard is divided, until the last school years.

Literature professor and writer Nenad Veličković believes that what Bosnia and Herzegovina offers today is not education, but indoctrination: the molding of children into national objects / subjects. In his words:

The main purpose here is to educate children to love their collectivity and the conquered territory, so when they grow up they will be ready to sacrifice themselves for this collectivity. [...] A nationalistic education cannot be good or of good quality, and it is not in the interest of the children. Children leave school with a defined stance based on an indoctrination process... If the media is not pleasing you, you can stop reading the newspaper or you can change the channel on television, but at school there is no free choice. Children are there to listen, so what you have there is a form of violence, because indoctrination is violence (2016). ${ }^{45}$

The connection between school education and "indoctrination" is not new. Bourdieu (Cf. 1998) pointed out that school, as well as national bureaucracies, constitute a place for exercising a symbolic violence, which contributes to the homogenization of the state. In this way, schools indeed educate individuals for the nation.

Therefore, indoctrination for Veličković or symbolic violence for Bourdieu is something normal in school curriculums of every country. However, in the case we analyze here from Bosnia and Herzegovina, this effort is made by transforming history into culture and culture into an emblem, which is often void of historicity. In Brčko, this happens in a single physical space, between four walls, where a group is defined by establishing an opposition with or by denying the other, either as a member of a group or as an individual.

In everyday life, however, the possibilities for creating relationships differ. Azra Hromadžić, for example, conducted a study at the Mostar high school, which is considered to be an integrated school, ${ }^{46}$ where youth of mostly Bosniac and Croatian origins go to school in the same period, but attend classes separately according to their respective school program, Bosnian or Croatian. The only exception is Information Technology classes where they are all together (a condition required by the Japanese who donated computers to the school). According to Hromadžić, the only time for intimacy and interaction between these young people, and when they are not remembered whether they are Bosniacs, Croats or others, is when they are in the bathrooms sharing cigarettes and talking about other issues (verbal information). ${ }^{47}$

Young people learn in life and at school that they are different. An anecdote may help to illustrate this. I was having a coffee with my neighbor in Sarajevo when she told me a story that she thought was very funny about her granddaughter. My neighbor's son, his wife and their three daughters had been living until the previous year in Norway - which received many Bosniacs during and after the war, and until today is considered an attractive place to emigrate. They later moved to Sweden - which received many Serbs and still does. One of the girls, who was then about eight, began to go to school in Sweden and to make Serbian friends there. One day, she came home and said, "Mom, I'm talking Serbian to you now and not Bosnian!". "What do you mean?", the mother asked. And the girl answered: "I found out from my new friend that I understand and speak perfect Serbian."

\footnotetext{
45 Translated from the original to Portuguese by the author.

46 Mostar was completely divided by the war, Bosniacs were left on one side and Croats on the other side (while most Serbs left the city). This is the only school that welcomes students from both national groups, Bosniac and Croatian.

47 Lecture given by Hromadžić in Banja Luka, Muzički paviljon, on 18 May 2015, promoted by the NGO Oštra nula. On her research among youngsters and about the postwar period in Mostar, see: Hromadžić 2015.
} 
There is, therefore, a very subtle line between the possibilities to develop critical thinking at school which, for instance, recognizes the three languages as one - and an education which feeds the division and segregation between people in a plural society.

The educational system and state bureaucracies are all divided in three in Bosnia and Herzegovina. This process ultimately excludes from power and public life all other groups or persons not belonging to one of these three groups. Even those who belong to one of these groups may be excluded if they are not in the entity which represents them. In Brčko, where multinationalism is constructed, these divisions and the conflicts they forge become more evident. There are harsh consequences to this, since it takes place in a context in which groups were divided by a bloody war in which people were killed, expelled and raped simply because they had a name that connoted a certain national belonging. The "multiethnic" policies do not lead to inclusion or so-called "reconciliation", but to exclusion; as testified to by the monuments at the center of Brčko and by some aspects of the basic educational policies in Bosnia and Herzegovina.

\section{Policies of National belonging in Bosnia and Herzegovina: what about the others?}

Let us suppose that there were three and only three national groups (or nations) in Bosnia and Herzegovina: Bosniacs, of Muslim religion and Bosnian language; Serbs, of Orthodox Christian religion and Serbian language; and Croats, of Catholic religion and Croatian language. Let us also suppose that the war of the 1990s was a civil war in which well-defined national groups defended themselves against other groups to safeguard their legitimate territory. In this sense, the successful peace agreement would have ceded Serbian territory to the Serbs (Republika Srpska), Croatian and Bosnian territory to Croats and Bosniacs (the Federation, divided in 10 cantons, 8 with homogeneous population and 2 with mixed population), and established a zone inhabited by the three groups, the Brčko District. In this District, each group would have its space for religious worship and to honor its heroes and soldiers killed in battle to defend the nation. Each group would also have its own space respected in the political and educational systems. Life would return to normal and peace would be achieved.

However, why does everything that has been said so far, rather than leading to the desired normality, indicate a latent violence that resonates in the concern of many of my interlocutors in Brčko that there could be a new war that would start right in Brčko?

In general terms, echoing Živanović, differences became absolute in Bosnia and Herzegovina. In his words:

There are many expressions that indicate the nature and functioning of Bosnian-Herzegovinian society: absolutism of the ethnic matrix, tribalism, discrimination, reduction of human rights to exclusively collective rights, [...] annulment of the individual, etc. These expressions are revealed in much of this, and especially in the well-known fact that people do not live in Bosnia and Herzegovina, only Bosniacs, Serbs and Croats, and those treated as "others." This is how it is according to the Constitution and this is how life is today. Somewhere at the margins of this order is found a certain structure (unhappy and dislocated) called "mixed marriages" $(2012: 5)^{48}$

Normalization thus corresponds to the naturalization of the concept of identity as being ethnicnational, and in the molds established by the war, which guide certain concepts of history, language, territory, heritage and culture. Therefore, a person is perceived as nothing more than a member of a group and only as such deserves citizenship - or does not. This is because the political system in Bosnia and

48 Translated from the original to Portuguese by the author. 
Herzegovina is based on an ethnic-national citizenship, and thus only people inserted within this context are worthy of respect and recognition. Precisely for this reason, we can affirm that it is an exclusionary system that does not account for the existence of people who are outside of this scheme. This may be because they do not belong to one of the three groups (or they do not belong to them appropriately), or because they are sons and daughters of mixed marriages, who, depending on the circumstances, according to statistics, wind up belonging to one of the groups - or not. ${ }^{49}$ What is also not mentioned is the existence of a common past which, to use Ugrešić's (1998) expression, had been confiscated, including the language of this past. The current slogan is: remember and recollect to not forget (the war, the genocide, the aggressive nature of the conflict). The problem is that remembering in this context only becomes coherent through a forgetting of the common and shared past, which is seen as a big lie.

The war, therefore, was not enough to divide the people, although it was quite successful in organizing the territory according to the national groups. Politics and education continue to pursue this task, leading to the naturalization of differences. This process is promoted by public institutions, particularly schools, and by political institutions, such as the governmental-administrative system and the ethnic-national democracy. Meanwhile, by focusing on only certain characteristics of particular groups, minorities are created, who are at times majorities in one or another entity, or are considered to be in the category of "others", without the complete rights of full citizens and who do not belong anywhere. They, in turn, will demand their rights based precisely on recognition and respect for differences ${ }^{50}$ - thus, the system creates new majorities and minorities, while maintaining old problems..$^{51}$

In "The Politics of Recognition" (1994), Taylor points out that the critique of multiculturalists and of those who support the rights to difference in relation to liberalism is based on the fact that liberalism is blind to differences and stuck to a homogenizing universalism, which in reality is the façade of the ruler or of the hegemonic group. However, by claiming specific rights, the adepts of multiculturalism fall paradoxically into the same homogenizing trap. Taylor, analyzing the problem of procedural liberalism and its universal equal rights, as well of multiculturalism and its politics of difference or of equal recognition, helps us to illuminate the problem in Bosnia and Herzegovina, which in my view, rather than being resolved in Brčko, explodes more clearly there than in any other part of the country. The problem being not the blindness to the differences, but the blindness of the differences.

A multicultural, multiethnic or multinational society - I will use all terms here as synonyms - as the adjectives themselves demonstrate, is a society composed of several groups that somehow share or form a political community. In this sense, Brčko's unified educational system could have been forged as a solution based on pluralism or multiculturalism, by uniting all students in a single classroom and applying a common curricular program that would seek a critical opening to differences. That is, it would be a de facto policy of difference, recognition and respect, as advocated by Taylor. However, a fragmented school program that informs students in a single language that they are different, that they speak different

\footnotetext{
49 According to the 2013 census, a small number of people do not fit into these three groups (Cf. Popis 2016). I believe that many of them have finally adjusted to the system, since the system is not flexible enough to adapt to others beyond the constituent nations. In any case, this is a hypothesis, and no research has been done to confirm it.

50 An example: Dervo Sejdić, of Romani origin, and Jakob Finci, of Jewish origin - both groups that are not considered constitutive nations by the Constitution - are calling for greater political participation of members of non-constitutional nationalities in Bosnia and Herzegovina. The lawsuit they filed against Bosnia and Herzegovina, calling for a radical constitutional political reform and accusing the state of being segregationist and of not respecting human rights, was approved in 2009 by the European Court of Human Rights (Case of Sejdić-Finci v. Bosnia and Herzegovina, Cf. Grand, 2009). In an interview with Sejdić (on 7 October 2014, in Sarajevo), it seemed clear that a political system based on non-national citizenship would be impossible to implement. According to him, the only viable solution, although unlikely, would be the inclusion of other national groups as a fourth element in the tri-national political equation.

51 Habermas (1998) highlights this with respect to demands for national independence, which, in his point of view, are nothing more than demands for equal rights of citizenship when there is injustice.
} 
languages and belong to different groups which have different military monuments to represent them, and that therefore represent their side in history, seeks to create homogenization and separation rather than pluralism and coexistence.

It is therefore possible to conclude that peace is being constructed in Bosnia and Herzegovina in the same way that made war possible: by dividing and classifying policies, parties, national groups, schools, cafes, and people. These are all metaphorical monuments of a conflict which, thereby, perpetuates itself.

Received: June 01, 2017

Approved: March 01, 2018

Translated by Sandro Solaz Willig

Edited by Jeffrey Hoff

\section{References}

AGIER, Michel. 2011. Managing the Undesirables: refugee camps and humanitarian government. Translated by David Fernbach. Cambridge: Polity.

APPIAH, K. Anthony. 1996. "Race, culture, identity: misunderstood connections". In: A. Gutmann (eds.), Colour conscious: the political morality of race. Princeton: Princeton University. pp. 30-105.

ARMAKOLAS, Ioannis. 2007. "Sarajevo no more?: identity and the sense of place among Bosnian Serb Sarajevans in Republika Srpska”. In: X. Bougarel; E. Helms; G. Duijzings (eds.), The new Bosnian mosaic: identities, memories and moral claims in a post-war society. Hampshire: Ashgate. pp. 79-99.

ARENDT, Hannah. 1989. Origens do totalitarismo: anti-semitismo, imperialismo, totalitarismo. Tradução Roberto Raposo. São Paulo: Companhia das Letras.

BOURDIEU, Pierre. 1998. O poder simbólico. Tradução Fernando Tomaz. 2 ed. Rio de Janeiro: Bertrand do Brasil.

BRINGA, Tone. 1993. "Nationality categories, identification and identity formation in 'multinational' Bosnia. Anthropology of East Europe Review, 11(1-2): 115-128, autumn. Special issue: War among the Yugoslavs. . 1995. Being Muslim the Bosnian way: identity and community in a Central Bosnian village. Princeton: Princeton University.

CONSTITUTION OF BOSNIA AND HERZEGOVINA. 1995. Available at: <http://www.ccbh.ba/public/down/ USTAV_BOSNE_I_HERCEGOVINE_engl.pdf $>$. Accessed on: 10 Oct. 2018.

CVIJIĆ, Vuk Z. 2015. “Rehabilitovan Draža Mihailović”. Blic, Beograd, 14 maja 2015. Available at: <http:/| www.blic.rs/vesti/drustvo/rehabilitovan-draza-mihailovic/hl3x4ex>. Accessed on: 20 Oct. 2018.

ČEKIĆ, Smail. 2005. The aggression against the Republic of Bosnia and Herzegovina: planning, preparation, execution. Translation by Branka Ramadanović. Sarajevo: Institute for the Research of Crimes Against Humanity and International Law. v. 1.

DECLARAÇÃO Universal dos Direitos Humanos. 1948. Rio de Janeiro: UNIC, 2009. Available at: 〈http:|/www. dudh.org.br/wp-content/uploads/2014/12/dudh.pdf >. Accessed on: 19 June 2016.

DERONJIĆ, Hamid. 2008. Rat za brčanski koridor. Sarajevo: (s.n.).

FARRAND, Robert W. 2011. Reconstruction and peace building in the Balkans: the Brčko experience. In collaboration with A. Frendak-Blume. Lanham: Rowman \& Littlefield Publishers.

GRAND Chamber judgment: Sejdic and Finci v. Bosnia and Herzegovina. European Court of Human Rights, 
Strasbourg, 2009. Available at: <http://hudoc.echr.coe.int/sites/eng-press/pages/search.aspx?i=0032974573-3281658>. Accessed on: 28 Oct. 2018.

GRANDITS, Hannes; PROMITZER, Christian. 2000. '“Former comrades' at war: historical perspectives on 'ethnic cleansing' in Croatia”. In: J. Halpern; D. Kideckel (eds.), Neighbors at war: anthropological perspectives on Yugoslav ethnicity, culture, and history. University Park: Pennsylvania University. pp.125142.

HABERMAS, Jürgen. nov. 1998. "Inclusão: integrar ou incorporar? Sobre a relação entre nação, estado de direito e democracia”. Novos Estudos Cebrap, 52: 99-120.

HROMADŽIĆ, Azra. 2015. Citizens of an empty nation: Youth and state-Making in postwar Bosnia-Herzegovina. Philadelphia: University of Pennsylvania.

JEFFREY, Alex. 2013. The Improvised State: Sovereignty, Performance and Agency in Dayton Bosnia. Oxford: Wiley-Blackwell.

MAČEK, Ivana. 2007. "Imitation of life': negotiating normality and the cultural transformation of Sarajevo". In: X. Bougarel; E. Helms; G. Duijzings (eds.), The new Bosnian mosaic: identities, memories and moral claims in a post-war society. Hampshire: Ashgate. pp. 39-57. . 2009. Sarajevo under siege: anthropology in wartime. Philadelphia: University of Pennsylvania.

MONTERO, Paula; ARRUTI, José Maurício; POMPA, Cristina. 2011. "Para una antropología de lo político". In: A. G. Lavalle (coord.), El horizonte de la política: Brasil y la agenda contemporánea de investigación en el debate internacional. México: Centro de Investigaciones y Estudios Superiores en Antropología Social. pp. 169-206.

MOORE, Roderick W. 15 Years of Brčko Supervision. 2013. Available at: <http://www.brckosupervizija.ba/ web/>. Accessed on: 20 Oct. 2018.

NA TOROVE razbroj s'!: izvještaj o segregatnom stanju. 2015. Školegijum, Sarajevo, 4(11): 18-25.

NACIONALNI sastav stanovništva: rezultati za republiku po opštinama i naseljenim mjestima 1991. Popis stanovništva, domaćinstava, stanova i polioprivrednih gazdinstava. 1991. Sarajevo: Državni zavod za statistiku Republike Bosne i Hercegovine.

OBRAZOVANJE u Bosni i Hercegovini: čemu učimo djecu? Analiza sadržaja udžbenika nacionalne grupe predmeta. 2007. Sarajevo: Fond otvoreno društvo Bosna i Hercegovina.

OSNOVNI pravni tekstovi u vezi sa Brčko Distriktom Bosne i Hercegovine $=$ Essential legal texts of the Brcko District of Bosnia and Herzegovina. Priredila Nataša Malinić. Brčko: Skupština Brčko Distrikta BiH, 2009. Available at: $\langle$ http:/|www.brckosupervizija.ba/Booklet_Essential_Legal_Texts.zip $\rangle$. Accessed on: 25 Oct. 2018.

PAO Gregorijanov nalog: Brčko bez spomenika civilnim žrtvama. 2013. eBrčko, Brčko, 12 avg. Available at: <http://www.ebrcko.net/vijesti/arhivirane-vijesti/118og-pao-gregorijanov-nalog-brcko-bez-spomenikacivilnim-zrtvama>. Accessed on: 20 Oct. 2018.

PAŠALIĆ, Enes. 2009. “Spomenici u Brčkom”. In: Godišnjak. Sarajevo: BZK Preporod. pp. 54-72.

“Zašto građani Brčko distrikta moraju u ličnu kartu upisivati entitetsko državljanstvo?” 2016. Patria: bh. novinska agencija, Sarajevo, 11 jan. Available at: 〈http://www.nap.ba/new/vijest.php?id=20263〉. Accessed on: 20 Oct. 2018.

PERES, Andréa Carolina Schvartz. 2005. Enviado especial à...: uma análise antropológica da cobertura da imprensa brasileira das guerras na ex-Iugoslávia (anos 9o). Dissertação de Mestrado em Antropologia Social, Universidade Estadual de Campinas, Campinas. . 2010. Contando histórias: fixers em Sarajevo. Tese de Doutorado em Antropologia Social, Universidade Estadual de Campinas, Campinas.

. “O debate sobre a representação da diferença e o significado da guerra na Bósnia-Herzegóvina”. 2013. 
Horizontes Antropológicos, 19(40): 423-450.

POPIS stanovništva, domaćinstava i stanova u Bosni i Hercegovini, 2013. Rezultati popisa / Cenzus of population, households and dwellings in Bosnia and Herzegovina, 2013. Final results. 2016. Sarajevo: Agencija za statistiku Bosne i Hercegovine.

SECURITY Council. 1996. “Resolution 1037”, 15 Jan. 1996. Available at: <https:|/daccess-ods.un.org/ TMP/2295095.02649307.html>. Accessed on: 20 set. 2017.

SHAHEED, Farida. 2014. "Report of the Special Rapporteur in the field of cultural rights. Addendum". Mission to Bosnia and Herzegovina (13 - 24 May 2013). 3 Mar. 2014. A/HRC/25/49/Add.1. Available at: <http://www.ohchr.org/EN/HRBodies/HRC/RegularSessions/Session25/Documents/A_HRC_25_49_ Add.1_ENG.DOC>. Accessed on: 20 Oct. 2018.

TAYLOR, Charles. 1994. “The politics of recognition”. In: . et al (eds.), Multiculturalism: examining the politics of recognition. Edited and Introduced by Amy Gutmann. Princeton: Princeton University. pp. 25-73. UGREŠIĆ, Dubravka. 1998. The Culture of Lies: antipolitical essays. Translated by Celia Hawkesworth. University Park, PA: The Pennsylvania State University.

VELIČKOVIĆ, Nenad. 2006. Konačari. Sarajevo: Omnibus. . 2015. Školokrečina: nacionalizam u bošnjačkim, srpskim i hrvatskim čitankama. Sarajevo: Lektira. . Nacionalističko obrazovanje je nasilje nad djecom. 2016. Novosti, 12 srpnja. Interviewed by Eldin Hadžović. Available at: <http://www.portalnovosti.com/nenad-velikovi-nacionalistiko-obrazovanje-jenasilje-nad-djecom?alphabet=mixed $>$. Accessed on: 20 Oct. 2018.

ZLOTRG, Sandra; VUKOVIĆ, Kaudija Mlakić. 2016. Principi prije pravila: Školski pravopisni priručnik. Sarajevo: Mas Media Sarajevo; Fond otvoreno društvo BiH.

ŽIVANOVIĆ, Miodrag. 2012. "Konstrukcija tragedije i(li) tragedija konstrukcije - jedan mogući komentar o fenomenu 'mješovitih brakova'. Predgovor”. In: N. Perišić (ed.), Mješoviti brak u BiH: od poželjnog do prezrenog, mješoviti brak kao kulturna i politička kategorija u savremenoj BiH. Sarajevo: Friedrich-EbertStiftung. pp. 5-6.

\section{Andréa Carolina Schvartz Peres}

Federal University at Roraima (UFRR)

The Brazilian Center of Analysis and Planning (Cebrap)

State University of Campinas (Unicamp)

https://orcid.org/oooo-0002-5323-8042

E-mail: acsperes@gmail.com 